\title{
Molecular Studies on E.coli Isolate from Milk of Mastitic Cattle with Special Reference to Associated Biochemical Changes in Kaliobea Governorate
}

\author{
Mervat Radwan
}

\begin{abstract}
This investigation was performed in Teaching Hospital and arm of Benha University in Moshtohor. The number of cows in this farm 80 dairy cows. 40 of them had clinical signs of mastitis (inflammation in teats, pain in milking and milk decrease in amount and quality). Weexamine these cows to identify the cause of these signs. California Mastitis Test (CMT) was performed to determine positive milk samples in the mastitic targeted cows. 20 samples of early lactation stage cows were recovered from 40 CMT- positive milk samples. Biochemical and PCR tests were performed to isolates E. Coli from positive milk samples (CMT) and determined three virulance genes, eae gene,SXT1 and SXT2. The significance of Escherichia coli-induced mastitis and biochemical changes associated to it in cows, due to the presence of virulence genes and resistance to awide range of 20 antimicrobials, is concluded. E.coli cause biochemical changes in mastitic cow as liver enzymes AST, GPT, TP,. Oxidativeenzymes as CAT, SOD, GST, LDand kidney function as urea and creatinine. E.coli has effect on inflammatory response inmastitic cow immunity system of by L6, TNF and CRP.
\end{abstract}

Keywords: Mastitis, Serotyping characterization, PCR, biochemical alteration

\section{INTRODUCTION}

Mastitis is an inflammation of the mammary glands associated with physical, and chemical and microbiological changes. It is considered the most important disease in dairy herds (Acik etal., 2004)[1]. The most important causitave mastitis - causative environmental pathogen is E.coli (Mokovee and Ruegge, 2003) [2].Escherichia coli is a major etiological agent of intra-mammary infections (IMI) in cows, leading to acute mastitis and causing great economic losses in dairy production worldwide (Blum, 2015 [3]). Particular strains cause persistent IMI, leading to recurrent mastitis. Virulence factors of mammary pathogenic E. coli (MPEC) involved pathogenesis of mastitis as well as those differentiating strains causing acute or persistent mastitis (Burvenich etal,2003 [4]) . The infection occur after bacteria entrance mammary gland via teat canal,overcoming anatomical barrier so they must evade the cellular and humoral defence mechanism of mammary gland to establish disease (Radostits et al., 2007 [5] and Mbuk, 2016) 6.. Limited number of E.coli strains has ability to adhere and invade bovine mammary epithelial cells and cause persistant infection,have several fimbria and fimbrial adhesion that mediat adhesion to host epithelial cell through cell surface (MILANOV,Dubravka 2015 [ 7] and Dopfer etal., 2000)[8]. This study was performed to detect the causitive agent of clinical mastitis in cow by isolation of E.coli from milk of mastatic cow with special refrence to biochemical changes associated to it in infected cow.Charactarization of E.coli pathogen isolated from mastitic cow chemical and serlogicaly.Investigation of some virulance factor associated to isolated E.coli . Detection of E.coli attaching and enfacing (Intimin) eaeA,STX1 and STX2 virulence factors of E. coli comprise adhesins, which help the bacteria to adhere to and colonize mucosal surfaces, and toxins, which are proteins with the ability to disturb or modify the normal function of the host cell and to help the bacteria to cross the epithelial barrier and to invade the tissue (Kaper et al., 2004)[9]. Clinical E. coli mastitis can range from mild with only local signs to severe disease with systemic clinical signs. In severe cases the outcome can be acute tissue damage and complete loss of milk production or even the death of the diseased cow. The severity of E. coli mastitis depends on the age of the cow and on the lactation stage, i.e. older cows and cows in early lactation are more susceptible to infection (Mehrzad et al., 2002)[10]. The general aim of this study was: 1-To investigate host response to Escherichia coli infection represented inby biochemical 
changes and immunity system reponse, 2-To identify possible specific virulence genes and phylogeny types of E. coli associated with severity of clinical mastitis and the intramammary infection.

\section{MATERIAL AND METHODS}

\subsection{Samples}

A total 40 of milk samples were collected from clinically mastitic cows from Quliobea Kaliobea Governorate. All samples were collected in sterilemacartins and perform (CMT).The positive samples will send as soon as possible to lab to be for examination. Bacteriological examination of milk samples (Qurnn etal. 2002)[11]. The collected samples were incubate aerobically at 37C for 18-24 hrs. then centrifuge date at $3000 \mathrm{rpm} / 20 \mathrm{~min}$ the cream and supernatant layer were discarded and streak the sediment on blood agar, Mac Conkey agar and EMBagar. The plates were incubated aerobically at $37^{\circ} \mathrm{C}$ for $24-48 \mathrm{hrs}$ and examined for bacteriological growth. Suspected colonies appeared on different media were picked up and purified by subculture on fresh set of protective and preserved into semisolid agar for Identification of isolated m.o. According to colonial morphological and appearance, growth characterization, hemolytic patterns, microscopically by Giemsa stain and biochemically changes according to (Boerlin etal., 2003) [12]

- Morphologically

- Biochemically identification

$\begin{array}{ll}\text { 1-Catalase } & \text { 2-Oxidase } \\ \text { 3-TSI } & \text { 3-Urease } \\ \text { 5-Indole } & \text { 6-MR } \\ \text { 7-VR } & \text { 8-Citrate } \\ \text { 9-Nitrate } & \text { 10-Sugar fermentation }\end{array}$

- Serological identification according to (Edwards and Ewing 1972)[13]

- PCR molecular identification

\subsection{DNA extraction}

DNA extraction from samples was performed using the QIAamp DNA Mini kit (Qiagen, Germany, $\mathrm{GmbH}$ ) with modifications from the manufacturer's recommendations. Briefly, $200 \mu 1$ of the sample suspension was incubated with $10 \mu \mathrm{l}$ of proteinase $\mathrm{K}$ and $200 \mu \mathrm{l}$ of lysis buffer at $56^{\circ} \mathrm{C}$ for $10 \mathrm{~min}$. After incubation, $200 \mu \mathrm{l}$ of $100 \%$ ethanol was added to the lysate. The sample was then washed and centrifuged following the manufacturer's recommendations. Nucleic acid was eluted with $100 \mu 1$ of elution buffer provided in the kit.

\subsection{Oligonucleotide Primer}

Primers used were supplied from Metabion (Germany) are listed in table(3)PCR amplification. Primers were utilized in a 25- $\mu \mathrm{l}$ reaction containing $12.5 \mu \mathrm{l}$ of EmeraldAmp Max PCR Master Mix (Takara, Japan), $1 \mu \mathrm{l}$ of each primer of 20 pmol concentration, $4.5 \mu 1$ of water, and $6 \mu 1$ of DNA template. The reaction was performed in an Applied biosystem 2720 thermal cycler. For stx1,2 duplex PCR, primers were utilized in a 50- $\mu 1$ reaction containing $25 \mu \mathrm{l}$ of EmeraldAmp Max PCR Master Mix, $1 \mu \mathrm{l}$ of each primer of 20 pmol concentration, $13 \mu 1$ of water, and $8 \mu 1$ of DNA template.

\section{AnAlysis of the PCR Products}

The products of PCR were separated by electrophoresis on 1.5\% agarose gel (Applichem, Germany, $\mathrm{GmbH}$ ) in 1x TBE buffer at room temperature using gradients of $5 \mathrm{~V} / \mathrm{cm}$. For gel analysis, $20 \mu \mathrm{l}$ of each PCR product were loaded in each gel slot. A Generuler 100 bp ladder (Fermentas, Thermo Scientific, Germany) was used to determine the fragment sizes. The gel was photographed by a gel documentation system (Alpha Innotech, Biometra) and the data was analyzed through computer software. 
Molecular Studies on E.coli Isolate from Milk of Mastitic Cattle with Special Reference to Associated Biochemical Changes in Kaliobea Governorate

Table1. Primers sequences, target genes, amplicon sizes and cycling conditions.

\begin{tabular}{|c|c|c|c|c|c|c|c|c|}
\hline \multirow{2}{*}{ Target gene } & \multirow{2}{*}{$\begin{array}{c}\text { Primers } \\
\text { sequences } \\
5^{\prime}-3^{\prime}\end{array}$} & \multirow{2}{*}{$\begin{array}{l}\text { Amplified } \\
\text { segment } \\
\text { (bp) }\end{array}$} & \multirow{2}{*}{$\begin{array}{l}\text { Primary } \\
\text { Denatura } \\
\text { tion }\end{array}$} & \multicolumn{3}{|c|}{ Amplification ( 35 cycles) } & \multirow{2}{*}{$\begin{array}{c}\text { Final } \\
\text { exten } \\
\text { sion }\end{array}$} & \multirow{2}{*}{$\begin{array}{c}\text { Refer } \\
\text { ence }\end{array}$} \\
\hline & & & & $\begin{array}{c}\text { Seconda } \\
\text { ry } \\
\text { denatur } \\
\text { ation }\end{array}$ & $\begin{array}{c}\text { Annea } \\
\text { ling }\end{array}$ & $\begin{array}{l}\text { Exten } \\
\text { sion }\end{array}$ & & \\
\hline \multirow[t]{2}{*}{ eaeA } & $\begin{array}{l}\text { ATGCTTAGTG } \\
\text { CTGGTTTAGG }\end{array}$ & \multirow[t]{2}{*}{248} & \multirow[t]{2}{*}{$\begin{array}{l}94^{\circ} \mathrm{C} \\
5 \mathrm{~min} .\end{array}$} & \multirow[t]{2}{*}{$\begin{array}{l}94^{\circ} \mathrm{C} \\
30 \mathrm{sec} .\end{array}$} & \multirow[t]{2}{*}{$\begin{array}{l}51^{\circ} \mathrm{C} \\
30 \mathrm{sec} .\end{array}$} & \multirow{2}{*}{$\begin{array}{l}72^{\circ} \mathrm{C} \\
30 \\
\text { sec. }\end{array}$} & \multirow{2}{*}{$\begin{array}{l}72^{\circ} \mathrm{C} \\
7 \\
\min .\end{array}$} & \multirow[t]{2}{*}{ [14] } \\
\hline & $\begin{array}{l}\text { GCCTTCATCA } \\
\text { TTTCGCTTTC }\end{array}$ & & & & & & & \\
\hline \multirow[t]{2}{*}{ Stx1 } & $\begin{array}{l}\text { ACACTGGATG } \\
\text { ATCTCAGTGG }\end{array}$ & \multirow[t]{2}{*}{614} & \multirow[t]{4}{*}{$\begin{array}{l}94^{\circ} \mathrm{C} \\
5 \mathrm{~min} .\end{array}$} & \multirow[t]{4}{*}{$\begin{array}{l}94^{\circ} \mathrm{C} \\
30 \mathrm{sec} .\end{array}$} & \multirow[t]{4}{*}{$\begin{array}{l}58^{\circ} \mathrm{C} \\
45 \mathrm{sec} .\end{array}$} & \multirow{4}{*}{$\begin{array}{l}72^{\circ} \mathrm{C} \\
45 \\
\text { sec. }\end{array}$} & \multirow{4}{*}{$\begin{array}{l}72^{\circ} \mathrm{C} \\
10 \\
\min .\end{array}$} & \multirow[t]{4}{*}[15]{} \\
\hline & $\begin{array}{l}\text { CTGAATCCCC } \\
\text { CTCCATTATG }\end{array}$ & & & & & & & \\
\hline \multirow[t]{2}{*}{ Stx2 } & $\begin{array}{l}\text { CCATGACAAC } \\
\text { GGACAGCAGT } \\
\mathrm{T}\end{array}$ & \multirow[t]{2}{*}{779} & & & & & & \\
\hline & $\begin{array}{l}\text { CCTGTCAACT } \\
\text { GAGCAGCACT } \\
\text { TTG }\end{array}$ & & & & & & & \\
\hline
\end{tabular}

\section{RESUlT}

Table2. Characterization of E.coli isolated from mastatic milk

\begin{tabular}{|l|l|l|}
\hline \multicolumn{1}{|c|}{ Test } & \multicolumn{1}{|c|}{ Reaction } & \multicolumn{1}{c|}{+ Ve } \\
\hline Gram stain & Gram -Ve medium size bacilli & $100 \%$ \\
\hline Biochemical Identification & & \\
\hline 1-catalase & Gas bubbles & $100 \%$ \\
\hline 2-Oxidase & -Ve & $0 \%$ \\
\hline Indol & Red ring & $100 \%$ \\
\hline 3-MR & Red colour & $100 \%$ \\
\hline 4-VR & - Ve & $0 \%$ \\
\hline 5-S.Citrate & -Ve & $0 \%$ \\
\hline 6-Urease & -Ve & $0 . \%$ \\
\hline 7-Tsi & A/A/ gas+H -H2S & $100 \%$ \\
\hline
\end{tabular}

Table3. Serotypes ofE.coli isolated from clinical mastitis cow

\begin{tabular}{|l|l|l|l|}
\hline $\begin{array}{c}\text { Noumber of mastatic } \\
\text { cows }\end{array}$ & Serotypes & Noumber & Percent \\
\hline \multirow{4}{*}{20} & O44 & 4 & $20 \%$ \\
\cline { 2 - 4 } & O55 & 3 & $15 \%$ \\
\cline { 2 - 4 } & O111 & 2 & $10 \%$ \\
\cline { 2 - 4 } & O124 & 2 & $10 \%$ \\
\cline { 2 - 4 } & O114 & 2 & $10 \%$ \\
\cline { 2 - 4 } & O158 & 2 & $10 \%$ \\
\cline { 2 - 4 } & O125 & 3 & $10 \%$ \\
\cline { 2 - 4 } & O26 & 2 & \\
\hline
\end{tabular}

Table4. Characterization of E.coli serogroup isolates recovered from milk samples of mastatic cow byPCR assays for Intamin,Stx1 and Stx 2

\begin{tabular}{|l|l|l|l|l|}
\hline \multirow{2}{*}{ Sample No. } & \multicolumn{1}{|c|}{ Sample ID } & \multicolumn{3}{c|}{ Results } \\
\cline { 3 - 5 } & & \multicolumn{1}{c|}{ eaeA } & \multicolumn{2}{c|}{ Stx1 } \\
\hline 1 & O44 & + & - & - \\
\hline 2 & O44 & + & + & - \\
\hline 3 & O55 & - & - & - \\
\hline 4 & O26 & + & - & - \\
\hline 5 & O114 & - & - & - \\
\hline 6 & O146 & + & - & + \\
\hline 7 & O158 & - & - & - \\
\hline 8 & 0125 & - & - & - \\
\hline
\end{tabular}


Table5. Biochemical changes associated to E.coli infection in serum of cows * value of $p<0.01$ and ** value of $p<0.001$.

\begin{tabular}{|c|c|c|c|c|c|c|c|c|c|c|c|}
\hline $\begin{array}{l}\text { G Groups } \\
\text { Parameters }\end{array}$ & CAT & SOD & LDH & $\overline{\mathbf{A L P}}$ & TP & $\begin{array}{c}\text { CREAT } \\
\text { INE }\end{array}$ & GOT & GST & GPT & UREA & MDA \\
\hline $\begin{array}{l}\text { CONTRO } \\
\text { L negative } \\
\text { groups }\end{array}$ & $\begin{array}{c}50.00 \\
\pm 4.103\end{array}$ & $\begin{array}{l}41.00 \\
\pm .512\end{array}$ & $\begin{array}{l}43.50 \\
\pm .272\end{array}$ & $\begin{array}{l}4.545 \pm .1 \\
69\end{array}$ & \begin{tabular}{|l|}
$8.463 \pm .2$ \\
24
\end{tabular} & $\begin{array}{l}0.5225 \\
\pm 0.04715\end{array}$ & $\begin{array}{l}56.50 \pm . \\
331\end{array}$ & \begin{tabular}{|l|}
241.0 \\
\pm 6.24
\end{tabular} & $\begin{array}{l}18.75 \pm \\
.287\end{array}$ & $\begin{array}{l}24.50 \pm \\
.661\end{array}$ & $\begin{array}{l}64.50 \\
\pm \\
4.252\end{array}$ \\
\hline $\begin{array}{c}\text { E.coli } \\
\text { Infected } \\
\text { groupa }\end{array}$ & $\begin{array}{l}19.83 \pm \\
1.470^{* * *}\end{array}$ & $\begin{array}{l}16.67 \pm 1 \\
.085^{* *}\end{array}$ & $\begin{array}{l}115.6 \pm \\
8.721^{* *}\end{array}$ & $\begin{array}{l}3.513 \\
\pm 0.116^{*}\end{array}$ & \begin{tabular}{|l|}
6.428 \\
\pm 0.1523
\end{tabular} & $\begin{array}{l}1.370 \\
\pm 0.1610\end{array}$ & $\begin{array}{l}81.40 \\
\pm 8.68^{* *}\end{array}$ & $\begin{array}{l}156.0 \\
\pm 5.31 \\
0\end{array}$ & $\begin{array}{l}53.20 \pm 3 . \\
137^{* *}\end{array}$ & $\begin{array}{l}44.67 \pm \\
3.252^{* *}\end{array}$ & $\begin{array}{l}139.6 \\
\pm 6.25 \\
8^{* *}\end{array}$ \\
\hline
\end{tabular}

Table6. In study Van ELISA for the quantitation of bovine TNF- $\alpha$ in plasma was modified for serum as described in (Carstensen et al., 2005)16 limit of the ELISA was $0.5 \mathrm{ng} / \mathrm{ml}$ for the serum.

\begin{tabular}{|l|l|l|}
\hline Groups Parameters & Control negative & E.coli infected \\
\hline IL6 & $81.50 \pm 5.362$ & $136.2 \pm 6.320^{*}$ \\
\hline TNF & $33.25 \pm 2.0564$ & $72.67 \pm 6.412^{*}$ \\
\hline CRP & $20.25 \pm 3.568$ & $96.00 \pm 6.261^{*}$ \\
\hline
\end{tabular}

*Value of $p<0.01$

Table1 explain Primers sequences, target genes, amplicon sizes and cycling conditions which used in preparation of DNA,Our results in Table 2and 3 showed that Characterization of E.coli isolated from mastitic milk by chemical tests which diffrantiation it from other cause of mastitis and other enterobactereacae ,table 2 determine strain of E.coli by Serotypes of E.coli isolated from clinical mastitis cow . table 4 showed that virulant genes present in strains O44eae, O44eaeand Stx1, O55, O26eae, O114, O146 eae and Stx2, O158, O125 .From begaining of table 5 and 6 table biochemical changes associated to infection appear in cows that infected with mastitis Tabie 5 : showed biochemical changes associated to E.coli infection in serum of cows while Tabie 6 :showed inflamatory response associated to E.Coli infection and immunity response . . Fig 1 showed abnormal changes in teat infected with E.coli showed inflamed and redness teat when compare with normal teat in other figure while Figure 2: agrose gel electrophoresis showed Intamin (eaeA, Stx1 and Stx2) genes from extracted DNA of E.coli serogroup (O55, O26, O114, O146 O158, and O125).
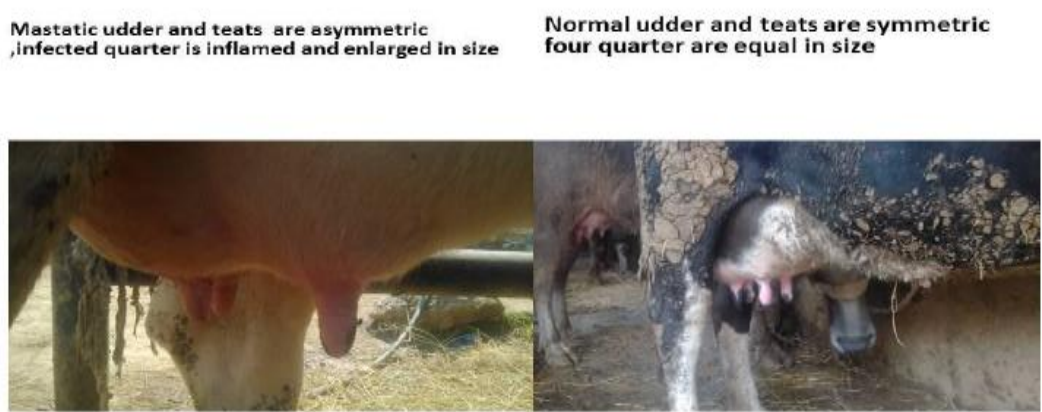

Figure1. Mastitis in cattle

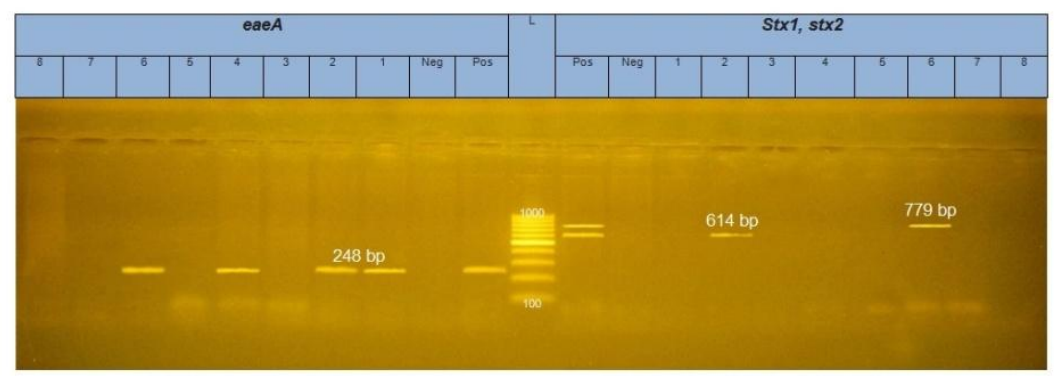

Figure2. 


\section{STATISTICAL ANALYSIS}

\subsection{Statistical Analysis Should be at Material and Methods Section}

The statistics was applied by means of SPSS software (SPSS ver. 16, Inc., Chicago, IL). T- Test was used for each group at a significant value at $\mathrm{p}<0.05$ Steel (1997) [.17]

\section{DisCuSSION}

The significance of Escherichia coli-induced mastitis in cows, associated with the presence of virulence genes, this targeted surveillance of rural dairy farms confirmed the significance of E. coli infection in mastitis of cows Elie etal., (2015) Escherichia coli is a major etiological agent of intramammary infections (IMI) in cows, leading to acute mastitis and causing great economic losses in dairy production worldwide(Bradley, 2001). Our result concluded that E.coli is the most cause of mastities by feild diagnosis CMTfound 20 out of 40 samples the causitive agent of mastities was pathogenic E.coli and confirmed by charachtarization of E.coli and biochemical analysis to determined strain of E.coli.This aforesaid results came in agreement with other reports which recorded that $\mathrm{E}$. coli is among the most common infectious agents isolated from severe mastitis cases in modern dairy farms (Bradley etand Bradley, 2002). The California Mastitis Test (CMT) provided a useful tool for farmers and veterinarians for measuring the level of inflammation in the udder(Elie, 2015)[22] .In current study founded increases in inflamatory parameters IL6,TNF andCRP factors. In our opinion, this elevation may be created as a result of proinflammatory response to infection with E.coli and stimulation of immunity system These aforesaid results came in agreement with other reports recoreded that LPS triggers formation of proinflammatory and inflammatory cytokines, produced predominantly by monocytes and macrophages (PerssonWaller et al., 2003[23]; Gonen etal., 2007)[24]. Cytokines, such as tumor necrosis factor alpha (TNF- $\alpha$ ), initiate the inflammatory response(Paape et al., 2003)[25], which induces the acute phase response (APR) by activating the production of acute phase proteins (APP) and LPS-binding protein (LBP) (Bannerman et al., 2003[26], Bannerman et al., 2004; Eckersall, 2001and Hiss et al., 2004).All the above mentioned alterationsmainly have a drawback effect on the biochemical and oxidative serum constituents specially SOD,LDH,ALB,TP, CREATINE, GOT, GST,GPT,Urea and MDA.Thesefactors were cowsdependent, like the speed of the inflammatory response, lactation stage and age of the cow, are thought to determine the severity of E. coli mastitis (Burvenich et al., 2003). The study advanced our standing of the mastitic effect of E.coli on cows . E.coli virulance genes which were detected by PCR were Itamin,SxT1 and SxT2 these toxins were isolated from strains( O44, O55, O111, O124, O114, O158,, O125, O26) were considered asvery important virulant factors of E.coli .Most of the pathogenic E. coli possesses several kinds of pathogenic mechanisms and virulence factors .Intimin is a protein encoded by eae gene (Ghanbarpour and Oswalt, 2010)[30]. It facilitates the adherence of attaching and effacing E. coli to the epithelial cells. It is proven that the eae gene in E. coli plays a definite role in induction of cattle mastitis(Correa and Marin, 2002) also this result came agree with(Kaper et al., 2004)who concluded that virulence factors of E. coli comprise adhesins, which help the bacteria to adhere to and colonize mucosal surfaces, and toxins, which are proteins with the ability to disturb or modify the normal function of the host cell and to help the bacteria to cross the epithelial barrier and to invade the tissue. There was a clear significant correlation between the CMT scores and the E. Coli, The presence of eae Intimin gene in E. coli involved in mastitis of dairy cows is of paramount importance, E. coli with Intimin gene are able to form small microcolonies on the surface of infected epithelial cells, followed by localized degeneration of the microvilli cumulating in an attaching and effacing (A/E) Elie et,al. (2015). all the E. coli isolates with the virulence genes stx and eae showed resistance to a higher number of antimicrobials than those which were stx-negative (Solomakos et al., 2009).

\section{Conclusion}

It is recommended in disease-control programs of dairy to study the E. coli involvement in mastitis, and to include in the surveillance the detection of virulence genes that are decisive in economic losses in vetrinarian . 


\section{REFERENCES}

[1] Ac ik ,M.N. , Yurdakul N.E. , akici L. C , Onat N. , Dogan,€O. , etinkaya B. C . 2004 traT and CNF2 genes of Escherichia coli isolated from milk of healthy cows and sheep .Department of Microbiology, Faculty of Veterinary Medicine, University of Firat, 23119 Elazig, Turkey

[2] Mokovee,J.ARuegge,P.L. (2003) Results of milk samples submitted for microbiological examination in Wisconsin from 1994 to 2001 J.DairySci . ,86:3466-3472 .

[3] Blum SE1, Heller ED2, Sela S3, Elad D4, Edery N5, Leitner G6. 2015. Genomic and Phenomic Study of Mammary Pathogenic Escherichia coli. PLoS One. Sep 1;10(9):e0136387. doi: 10.1371/journal.pone.0136387. eCollection 2015.

[4] Burvenich, C., Van Merris, V., Mehrzad, J., Diez-Fraile, A., Duchateau, L., 2003. Severity of E. coli mastitis is mainly determined by cow factors. Vet. Res. 34, 521-564.

[5] Radostits OM, Gay CC, Hinchcliff KW, Constable PD (2007). Diseases caused by fungi. Veterinary Medicine: A textbook of the diseases of cattle, horses, sheep, pigs and goats. 10th edition. Saunders Elsevier Ltd. Philadelphia, USA. pp. 842-860.

[6] Mbuk, E. U.1, Kwaga, J. K. P.1, Bale, J. O. O.2, Boro, L. A.3 and Umoh, J. U.2016 ,Coliform organisms associated with milk of cows with mastitis and their sensitivity to commonly available antibiotics in Kaduna State, Nigeria Journal of Vetrinary Mediciny and Animal Healthy Vol. 8(12), pp. 228-236, December

[7] MILANOV Dubravka*, PRUNIĆ Bojana, VELHNER Maja, TODOROVIĆ Dalibor, POLAČEK Vladimir 2015,INVESTIGATION OF BIOFILM FORMATION AND PHYLOGENETIC TYPING OF ESCHERICHIA COLI STRAINS ISOLATED FROM MILK OF COWS WITH MASTITIS ,Acta Veterinaria-Beograd 65 (2), 202-216.

[8] Döpfer, D., Almeida, R.A., Lam, T.J.G.M., Nederbragt, H., Oliver, S.P. and Gaastra, W., 2000. Adhesion and invasion of Escherichia coli from single and recurrent clinical cases of bovine mastitis in vitro. Vet. Microbiol. 74, 331-343

[9] Kaper, J.B., Nataro, J.P., Mobley, H.L., 2004. Pathogenic Escherichia coli. Nat. Rev. Microbiol. 2, 123-140.

[10] Mehrzad, J., Duchateau, L., Pyörälä, S., Burvenich, C., 2002. Blood and milk neutrophils chemiluminescence and viability in primiparous and pluriparous dairy cows during late pregnancy, around parturition and early lactation. J. Dairy Sci. 85, 3268-3276.

[11] Qurnn P.J.:Morky,B.K Cater M.E. Donelly W.J.C. and Leonard F.C.(2002)8 Vetrinary Microbiology and Microbial diseases . $1^{\text {st }}$ Low stat University Press Blackwell Scienc

[12] Boerlin P.Kuhnert,P. Hussy.D.andSchaellibaum ,M. 2003) Methods of identification of S.aureusisoletes in cases of bovine mastitis J.Clin.Microbial .41(2) : 767-771 .

[13] Edwered P.R. and Ewing W.H.( 1972) .Identification of Enterobacteriaceae .Burrgesspubi, Co.,Minneapolis, Minnesota ,103-104.

[14] Bisi-Johnson, M.A.; Obi, C.L.; Vasaikar, S.D.; Baba, K.A. and Hattori, T. (2011):Molecular basis of virulence in clinical isolates of Escherichia coli and Salmonella species from a tertiary hospital in the Eastern Cape, South Africa. Gut Pathogens 2011, 3:9.

[15] Dipineto, L.; Santaniello, A.; Fontanella, M.; Lagos, K.; Fioretti, A. and Menna, L.F. (2006). Presence of Shiga toxin-producing Escherichia coli O157:H7 in living layer hens. Letters in Applied Microbiology 43 (2006) 293-295.

[16] Carstensen, L., Rontved, C.M., Nielsen, J.P., 2005. Determination of tumor necrosis factoralpha responsiveness in piglets around weaning using an ex vivo whole blood stimulation assay. Vet Immunol. Immunopathol. 105, 59-66.

[17] Steel R, Torrie J, Dickey D (1997). Principles and procedures of Statistics: A Biometrical Approach, 3rd ed., McGraw-Hill, New York, NY.

[18] Elie K. Barbour,Tamar J. Kassabian, Houssam Shaib, Zeina Kassaify, Archana Iyer, Esam Azhar, Steve Harakeh, Taha Kumosan.(2015)The Significance of Escherichia coli-induced Mastitis in Cows Associated with the Presence of Virulence Genes and Wide Range-resistance to Twenty Antimicrobials 
Molecular Studies on E.coli Isolate from Milk of Mastitic Cattle with Special Reference to Associated Biochemical Changes in Kaliobea Governorate

[19] Bradley AJ, Green MJ: 2001, Adaptation of Escherichia coli to the bovine mammary gland. Journal of Clinical Microbiology 39: 1845-1849.

[20] Bradley, A.J., Leach, K.A., Breen, J.E., Green, L.E., Green, M.J., 2007. Survey of the incidence and aetiology of mastitis in dairy farms in England and Wales. Vet. Rec. 160, 253-258

[21] Bradley, A. 2002 Bovine mastitis an evolving disease ,The vetrinary Journal 164,116-128

[22] Persson Waller, K., Colditz, I.G., Lun, S., Östensson, K., 2003. Cytokines in mammary lymph and milk during endotoxin-induced bovine mastitis. Res Vet Sci. 74, 31-6.

[23] Gonen, E., Vallon-Eberhard, A., Elazar, S., Harmelin, A., Brenner, O., Rosenshine, I., Jung, S., Shpigel, N., 2007. Toll-like receptor 4 is needed to restrict the invasion of Escherichia coli P4 into mammary gland epithelial cells in a murine model of acute mastitis. Cellular Microbiology, doi: 10.1111/j.1462-5822.2007.00999.x.

[24] Paape, M., Bannerman, D., Zhao, X., Lee, J.W., 2003. The bovine neutrophil: +structure and function in blood and milk. Vet. Res. 34, 597-627.

[25] Bannerman, D.D., Paape, M.J., Hare, W.R., Sohn, E.J., 2003. Increased levels of LPSbinding protein in bovine blood and milk following bacterial lipopolysaccharide challenge. J. Dairy Sci. 86, 3128-3137.

[26] Bannerman, D.D., Paape, M.J., Lee, J.W., Zhao, X., Hope, J.C., Rainard, P., 2004. Escherichia coli and Staphylococcus aureus elicit differential innate immune responses following intramammary infection. Clin. Diagn. Lab. Immunol. 11, 463-472.

[27] Eckersall, P.D., Young, F.J., McComb, C., Hogarth, C.J., Safi, S., Weber, A., McDonald, T., Nolan, A.M., Fitzpatrick, J.L., 2001. Acute phase proteins in serum and milk from dairy cows with clinical mastitis. Vet. Rec. 148, 35-41.

[28] Hiss, S., Mielenz, M., Bruckmaier, R.M., Sauerwein, H., 2004. Haptoglobin concentrations in blood and milk after endotoxin challenge and quantification of mammary Hp mRNA expression. J. Dairy Sci. 87, 3778-3784.

[29] Ghanbarpour R, Oswald E. Phylogenetic distribution of virulence genes in Escherichia coli isolated from bovine mastitis in Iran. Res Vet Sci. 2010; 88:6-10.

[30] Correa MGP, Marin JM. O-serogroups, eae gene and EAF plasmid in Escherichia coli isolates from cases of bovine mastitis in Brazil. Vet Microbiol. 2002; 85:125-132.

[31] Solomakos N, Govaris A, Angelidis AS, Pournaras S, Burriel,AR, Kritas SK, Papageorgiou DK. Occurrence, virulence genes and antibiotic resistance of Escherichia coli O157 isolated from raw bovine, caprine and ovine milk in Greece. Food Microbiol. 2009; $26: 865$ - 871.

Citation: M. Radwan, "Molecular Studies on E.coli Isolate from Milk of Mastitic Cattle with Special Reference to Associated Biochemical Changes in Kaliobea Governorate", International Journal of Research Studies in Biosciences (IJRSB), vol. 5, no. 8, p. 33, 2017. http://dx.doi.org/10.20431/2349-0365.0508005.

Copyright: (C) 2017 Authors. This is an open-access article distributed under the terms of the Creative Commons Attribution License, which permits unrestricted use, distribution, and reproduction in any medium, provided the original author and source are credited. 